\title{
The susceptibility to pollution of groundwater occurring in a paper production area: Rio Claro (SP), Brazil
}

\author{
D. M. Bonotto ${ }^{1}$, J. R. Jiménez-Rueda ${ }^{1}$, F. Y. Hiodo ${ }^{2}$ \\ \& F. B. Ribeiro ${ }^{2}$ \\ ${ }^{1}$ Departamento de Petrologia e Metalogenia, \\ Instituto de Geociências e Ciências Exatas-UNESP, Rio Claro, Brazil \\ ${ }^{2}$ Departamento de Geofisica, Instituto de Astronomia, Geofísica \\ e Ciências Atmosféricas, USP, São Paulo, Brazil
}

\begin{abstract}
This investigation was carried out at Rio Claro city, São Paulo State, Brazil, and involved the study of an area of a local industry dedicated to paper production. The study was held as a requirement of CETESB (São Paulo State Company of Technology and Environmental Sanitation) that is the environmental agency of São Paulo State responsible for the control, fiscalization, monitoring and licensing of the activities that may cause pollution, with the major aim of preserving and recovering the quality of water, air and soil. The paper production involves the generation of solid waste where leaching may cause the release of liquids that are able to pollute the groundwater. Thus, it is necessary to know the basic properties of the soil cover where there is the intention to put the solid waste in order to evaluate its susceptibility to groundwater pollution. The evaluation of the selected site involved several steps, among them the knowledge of the climatic conditions and rainfall rate, characterization of the geological formations and of the soil types occurring between the ground surface and water table, water table depth and determination of the hydraulic conductivity coefficient. This paper describes all activities developed for attending the CETESB requirements.

Keywords: geophysical survey, groundwater contamination, paper production, waste disposal area.
\end{abstract}




\section{Introduction}

São Paulo State is located in southeastern Brazil, constituting the "heart" of the southeast. It borders the Atlantic Ocean to the southeast and is bounded by the states of Minas Gerais (northeast), Rio de Janeiro (east), Paraná (southwest), and Mato Grosso do Sul (west) (Fig. 1). The state itself accounts for more than onefifth of the Brazilian population. It produces more than half of the country's manufactures and the overwhelming majority of its population is urban and suburban. The state capital, São Paulo, is the largest city in Brazil and one of the largest urban centres in the world.

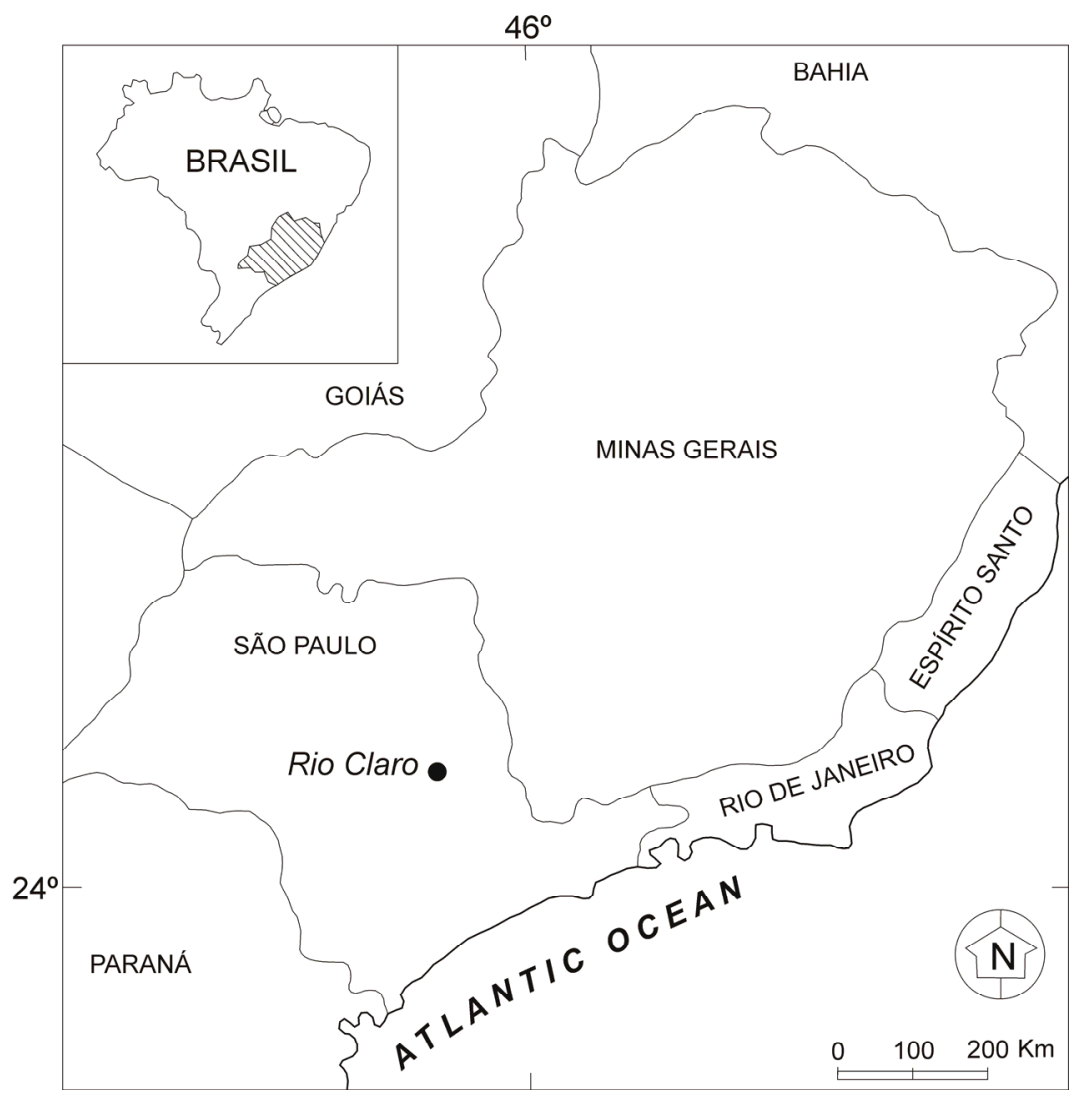

Figure 1: $\quad$ Location of Rio Claro city at São Paulo State, Brazil.

São Paulo is the most populous Brazilian states, comprising circa 40 million inhabitants distributed over 645 municipalities. It has the highest number of industries and economic production, reaching 31\% of the Brazilian GDP-gross domestic product. Despite the vigorous industrial production that includes high 
technology goods, the state also is well developed in agriculture and cattle breeding [1]. This advanced stage of agricultural and industrial growth causes to São Paulo State a great diversity of problems related to the interaction between the society and the environment, which may cause the pollution of soils, air, surface waters and groundwater.

The use of groundwater in São Paulo State has increased mainly in the last decade. It has been also expected a more accentuated increase in the next years, as a consequence of the technological advances of the sector coupled to the known advantageous of the groundwater in relation to superficial hydrological resources as, in principle, it is less subject do pollution.

The Departamento de Águas e Energia Elétrica (DAEE) in São Paulo State developed the project "Study of groundwater in São Paulo State" between 1973 and 1982 with the aim of performing a systematic field investigation of the aquifer units, of the conditions of the groundwater exploitation and of its main purpose of use [2]. Eleven regional surveys were conducted along circa 18 months that included Rio Claro city in Administrative Region No. 5, which comprised a total surface area of $27,000 \mathrm{~km}^{2}$ and a number of recorded tubular wells corresponding to about 2,000.

The Companhia de Tecnologia de Saneamento Ambiental (CETESB) was established in 1973 by the government of São Paulo State with the purpose of controlling the pollution of the hydrological resources, being linked to the Secretary of the Environment of the State of São Paulo. The permissible concentration limits in effluents to be released to water bodies were defined in São Paulo State by Register 997 published on 31 May 1976, being CETESB the agency responsible to verify if the emissions take place under the limiting values. CETESB has been also responsible by the establishment of guidelines for the appropriate residues storage and safe waste disposal on the ground.

Industrial activities involving the paper production have been held at Rio Claro city area by COMAPA-Paper Industry Ltd. In the period of the settlement of the installations, CETESB verified that some guidelines should be fitted for avoiding the release of effluents to surface waters and groundwater. This paper describes all field studies developed for attending the CETESB requirements.

\section{General features of the studied area}

The city of Rio Claro is situated at $22^{\circ} 23^{\prime} \mathrm{S}$ and $47^{\circ} 36^{\prime} \mathrm{W}$, having an area of about $540 \mathrm{~km}^{2}$ (Fig. 1). It is located at the northeastern edge of the Paraná sedimentary basin, cropping-out several stratigraphical units [3] of the basin in the region: Itararé Subgroup (sandstones, conglomerates, diamictites, tillites, siltstones, shales and rhythmites) and Tatuí Formation (siltstones, shales, silex and sandstones with local concretions) from Tubarão Group; Irati Formation (siltstones, mudstones, dark bituminous shales and limestones) and Corumbataí Formation (mudstones, shales and muddy sandstones) from Passa Dois Group; Pirambóia Formation (sandstones, shales and muddy sandstones), Botucatu Formation (sandstones and muddy sandstones), Serra Geral Formation (basalts and diabases) and related basic intrusives from São Bento Group; different types 
of Cenozoic covers like the Rio Claro Formation (sandstones, conglomerate sandstones and muddy sandstones), recent deposits and terrace sediments.

The climate of the region is Aw type (Köeppen classification), i.e. tropical rainy weather characterized by wet summer (October through March) and dry winter (April through September) [4]. The area often has 55-65 days of rain per year, with more than $80 \%$ of the precipitation falling between October and March [5].

The Rio Claro city is the most important municipality in the Corumbataí River basin that extends over an area of about $1581 \mathrm{~km}^{2}$ and includes the Corumbataí River (extension of about $120 \mathrm{~km}$ ) and tributaries (Claro stream, Passa Cinco River and Cabeças River). The Corumbataí River and affluents start flowing in the cuesta zone of the Depressão Periférica geomorphological province [6], reaching Piracicaba River after crossing Rio Claro city. Their waters are a very important resource for Rio Claro city, being utilized in the drinking water treatment plant of the municipality, reason by which special attention has been given by local authorities in terms of probable environmental impacts able to modify their quality.

Fig. 2 shows a sketch map of the investigated industry installations, where it is possible identify the presence of Corumbataí River, drying ponds and units utilized for storing the residues generated during the paper production process. One important aspect is that the waste should be directly deposited in the ground, whereas other significant feature is that the area is very close to Corumbataí River. The environmental authorities required a comprehensive physical study of the area to be used for storing the residues as groundwater pollution could occur, also implying on the water quality of Corumbataí River that drains the area and receives its groundwater discharge.

\section{Field studies}

The evaluation of the selected site involved several steps, among them the knowledge of the climatic conditions and rainfall rate, characterization of the geological formations and soil types occurring between the ground surface and water table, water table depth and determination of the hydraulic conductivity coefficient. The field studies were held in year 1997, allowing identify the following landscape features (Fig. 2): A.1 - Flooding plain; A.2.1 - Moderately dissected high plain; A.2.1.1 - Slightly sloped plain; P.3.2 - Moderately dissected low plateau; P.3.3 - Strongly dissected low plateau.

Two soil profiles were described in the area and according to the Brazilian System of Soils Classification [7] they can be considered as red-yellow latossols. The profile rc4 exhibited the following texture: clayey sandy loam in the more superficial horizons (up to $4 \mathrm{~m}$ depth) and clayey in the deeper horizons (between 4 and $7 \mathrm{~m}$ depth). The profile rc0 possessed the following texture: clayey sandy loam in the more superficial horizons (up to $5.5 \mathrm{~m}$ depth) and clayey in the deeper horizons (between 5.5 and $7 \mathrm{~m}$ depth). The clayey texture characterized the horizons related to the semi-weathered rock. 


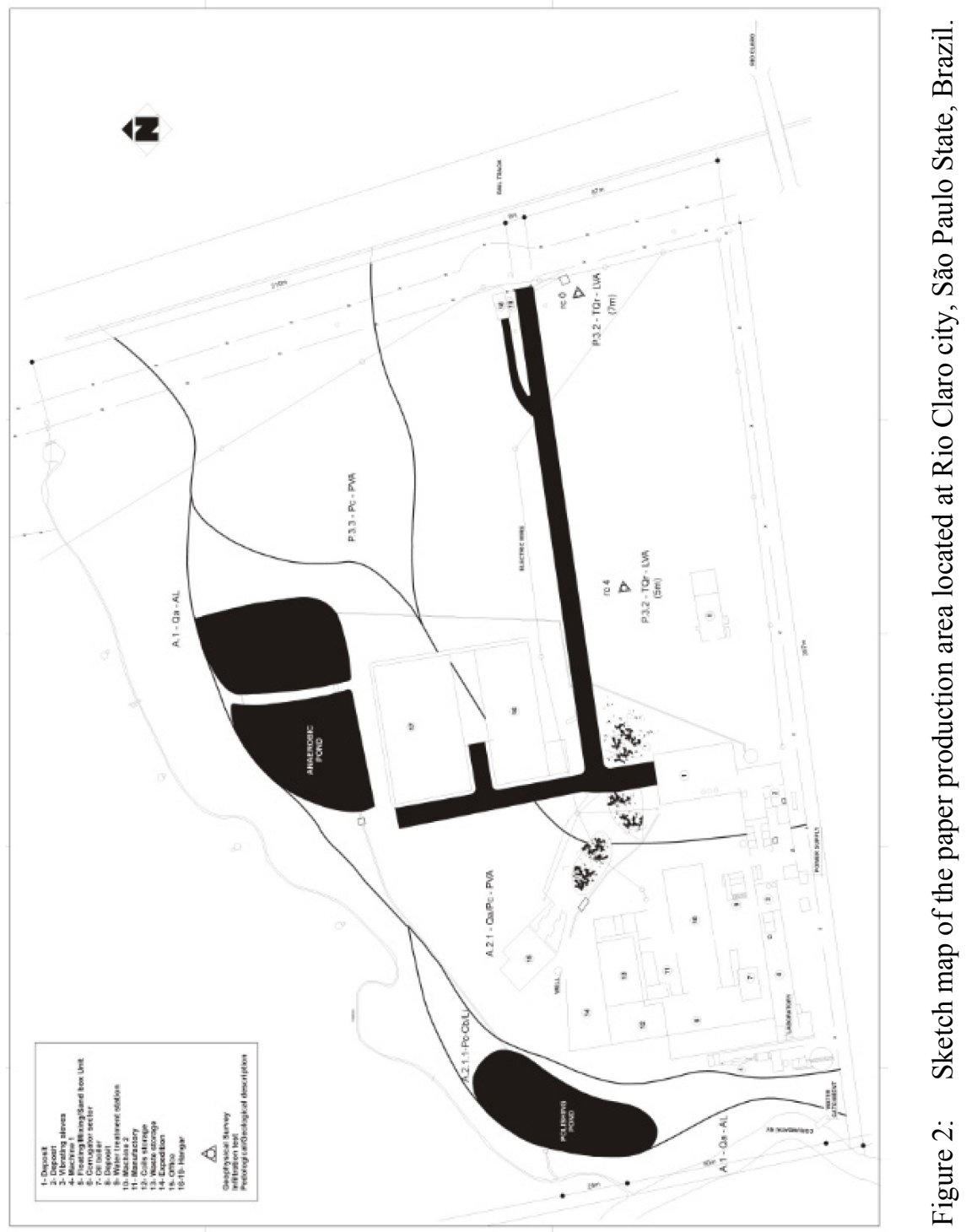


The geological characterization of the area indicated the presence of typical lithologies of Rio Claro Formation constituted by an upper sequence of little consolidated and non-structured reddish brown sandstones with accentuated latossolization degree that are typically of colluvial origin. There was also the presence of a lower sequence composed by fine to medium little consolidated yellowish sandstones which presented intercalations of claystone layers exhibiting variable thicknesses and/or associated gravels that confirm their alluvial genesis. In Fig. 2, Qa corresponds to alluvial sediments, Pc to Corumbataí Formation and TQr to Rio Claro Formation.

The pedogenesis of the red yellow latossols in the area is related to the array of the two sequences of Rio Claro Formation. The deeper horizons of these latossols present lithological discordance that is related to Corumbataí Formation of Passa-Dois Group, which is constituted by claystones, shales and purplish/reddish gray siltstones with intercalations of carbonatic benches, silexites and fine sandstone layers [3]. In Fig. 2, AL corresponds to alluvial soils, PVA $(\mathrm{Cb} / \mathrm{Li})$ to red-yellow podzols and LVA to red-yellow latossols.

\section{Climatic conditions and infiltration rate}

Table 1 reports some climatic data in year 1995 providing from [8], which indicate that the winds in winter tend to exhibit northeastern direction, whereas in summer the directions are quite variable.

The precipitation and evaporation in the period 1974-1995 corresponded to $1661.6 \mathrm{~mm}$ and $1036 \mathrm{~mm}$, respectively, referring to information valid in a regional context as provided by the hydric balance of IAC (Agronomical Institute of Campinas) according to the method of Thorthwaite and Mather [9]. However, the climatic Atlas of Rio Claro city [8] provided the following values in the period 1990-1995 for a rainfall monitoring station situated close to the studied area: annual average precipitation $=1691 \mathrm{~mm}$; potential evapotranspiration $=1209 \mathrm{~mm}$.

The infiltration in the study area was determined from an equation indicated by CETESB in the instructions reported in the Memorial for Characterizing the Installations - Systems for Waste Disposal in Soils. The value obtained corresponded to $641 \mathrm{~mm} /$ year.

Table 1: Dominant direction and winds speed at Rio Claro city area (according to [8]).

\begin{tabular}{lll|lll}
\hline Month & $\begin{array}{l}\text { Dominant } \\
\text { direction }\end{array}$ & $\begin{array}{l}\text { Speed } \\
(\mathrm{m} / \mathrm{s})\end{array}$ & Month & $\begin{array}{l}\text { Dominant } \\
\text { direction }\end{array}$ & $\begin{array}{l}\text { Speed } \\
(\mathrm{m} / \mathrm{s})\end{array}$ \\
\hline February & N-NE & 2.2 & August & NE-SW & 3.2 \\
March & S-SW & 3.2 & September & SW-NE & 3.2 \\
April & SW & 2.2 & October & SW-NE & 4.4 \\
May & SW & 2.2 & November & NE-SW & 3.2 \\
June & NE & 2.2 & December & SW-NE & 3.2 \\
July & NE & 3.2 & & & \\
\hline
\end{tabular}




\section{Water table depth}

The water table depth was evaluated by electro-resistivity geophysical surveys. The Schlumberger array was used to provide resistivity and loadability data, where the $\mathrm{AB} / 2$ opening of up to $120 \mathrm{~m}$ was adopted for the Syscal R2 resistivimeter (Fig. 3).

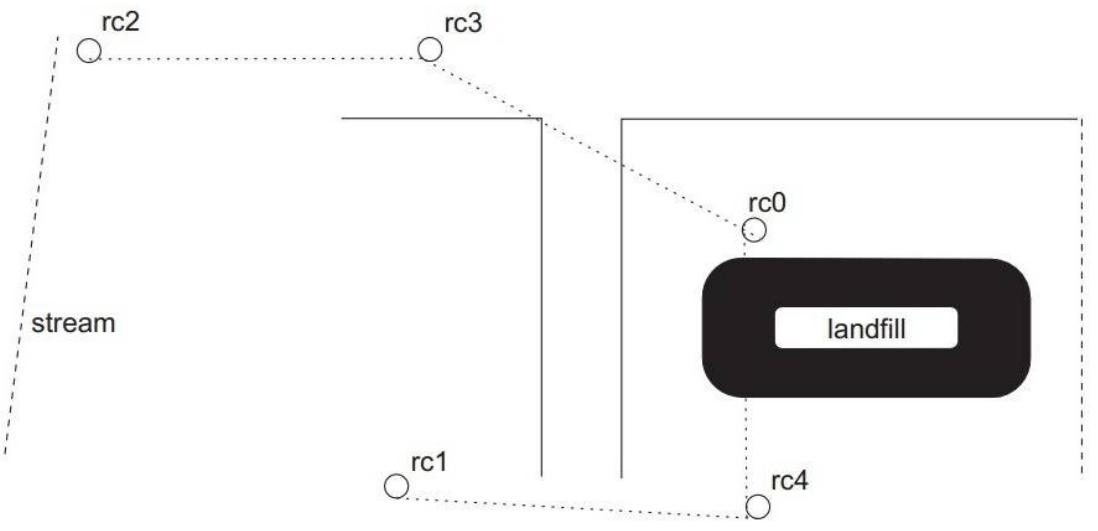

Figure 3: The Schlumberger array utilized in the study area.

According to geophysical models, the surveys indicated a possible terrain subdivision as follows: superficial soil, unsaturated horizon, saturated horizon and unaltered rock. The surveys realized around profile rc0 situated in the left side of industry entrance indicated that the water table is located at about $13.2 \mathrm{~m}$ depth (Fig. 4), whereas the surveys realized around profile re4 situated in the wood storage area indicated that the water table is located at about $15.7 \mathrm{~m}$ depth (Fig. 5).

\section{Hydraulic conductivity coefficient}

The natural materials have been classified by various authors according to their different values of the hydraulic conductivity coefficient $(\mathrm{K})$. According to the classes given in Table 2, $\mathrm{K}$ values between $10^{-4}$ and $10^{-6} \mathrm{~cm} / \mathrm{s}$ would imply on a "bad" category for the groundwater movement, corresponding to very fine sand, silt, and mixing of sand and clays.

The hydraulic conductivity coefficient was evaluated according to the field instructions established by the Brazilian Association of Geological Engineering [10]. The essays were realized in the basis of the profiles rc0 and rc4. PVC tubes 


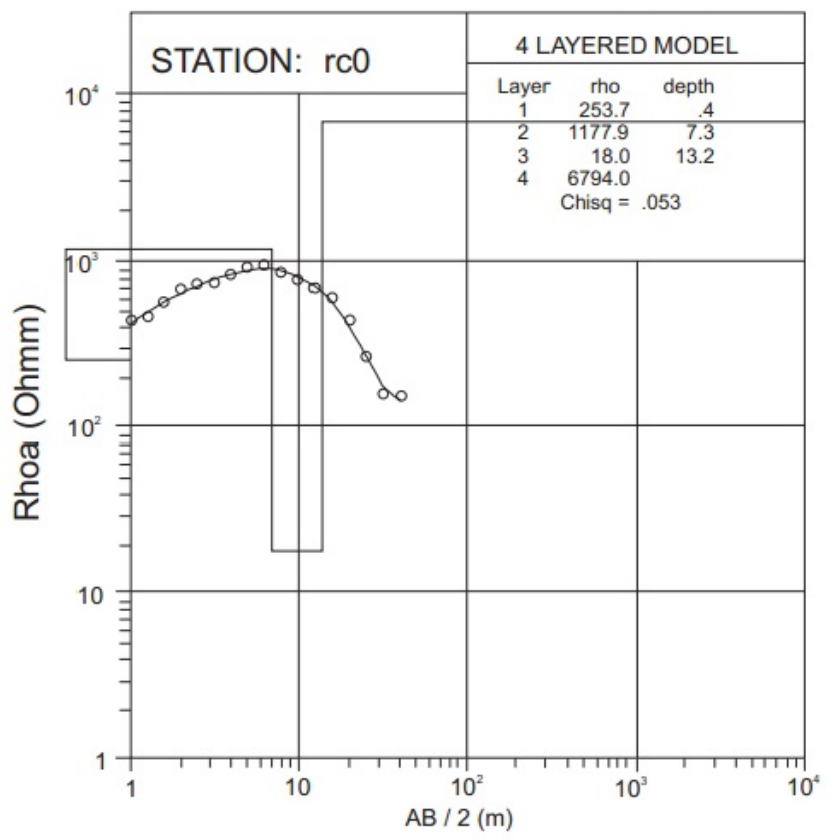

Figure 4: Geophysical survey realized around profile rc0.

were completely filled with water, corresponding the time zero to the instant when this happened. Then, the water supply was interrupted and its level started lowering. The measurement of the time with a chronometer started when the water level reached the "zero" position. The readings corresponded to centimeters reached by the water level in the scale. For instance, after $5 \mathrm{~s}$, a reading of the water level was taken. Then, the PVC tube was filled until the "zero" position and again the water supplying was stopped, determining how many centimeters the water level lowered, now in $10 \mathrm{~s}$. Thus, the process was successively repeated increasing the time to $30 \mathrm{~s}, 1 \mathrm{~min}, 2 \mathrm{~min}, 5 \mathrm{~min}, 10 \mathrm{~min}$, $15 \mathrm{~min}, 20 \mathrm{~min}, 30 \mathrm{~min}$, etc.

All data were recorded in an appropriate sheet for further evaluation of the hydraulic conductivity coefficient. The right moment for finishing the measurements was decided on verifying the instant in which the time for some readings was long enough compared to the small lowering of the water level, at least during four successive measurements. A linear regression involving the time and water level variation data allowed finding the best straight line adjusted to the results, from which it was evaluated the angular coefficient, a parameter necessary to apply in the equation for determining the hydraulic conductivity coefficient (K). Some caution was needed to perform the regression because of the initial points not fitting the straight line, even in mono-log graph. This is because they could represent the phase in which the moisture front was suffering 


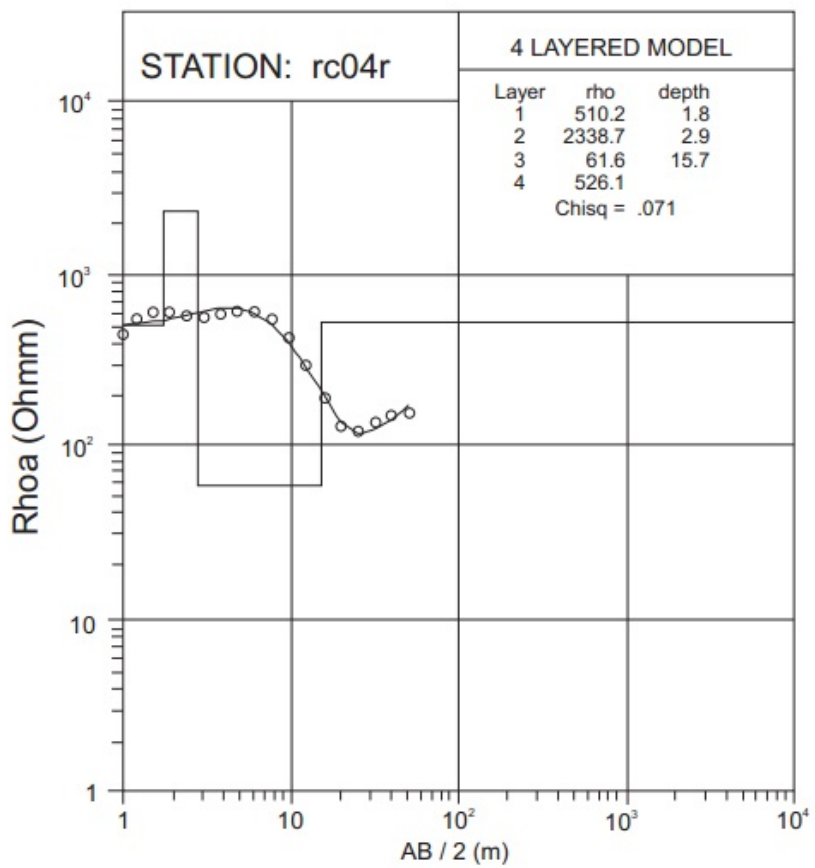

Figure 5: Geophysical survey realized around profile rc4.

Table 2: Classification of different materials according to the hydraulic conductivity coefficient (according to [11]).

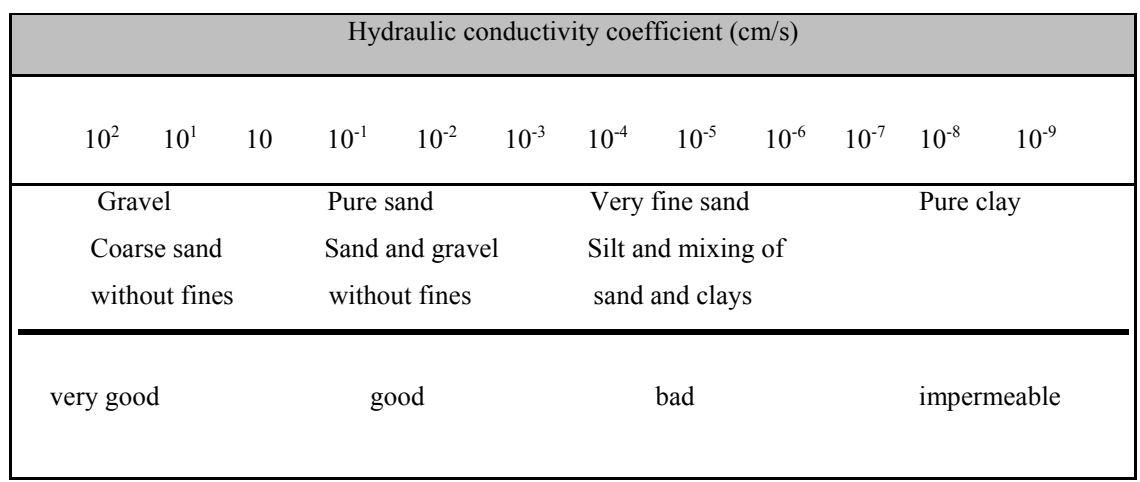


influence of adsorption and capillary forces of the porous medium, so that the steady state of the hydraulic flow had not been reached yet.

The infiltration test in profile re4 provided a hydraulic conductivity coefficient corresponding to $0.000191 \mathrm{~cm} / \mathrm{s}$, whereas the infiltration test held in profile rc0 yielded a value six times higher, i.e. $0.00111 \mathrm{~cm} / \mathrm{s}$. Both values are compatible with those expected for silty and clayey fine sands and clayey silts, confirming the approach realized by the two evaluations (field identification and field experiments).

\section{Conclusion}

The results of this study initially indicated that the waste of COMAPA-Paper Industry Ltd. belong to Class II according to the Brazilian guidelines, i.e. they correspond to general residues consisting mainly in paper and plastic (80\%). The CETESB Technical Rule No. 024/96/EETR points out that the maximum allowed value of hydraulic conductivity coefficient should be $0.00005 \mathrm{~cm} / \mathrm{s}$ that is lower than the values obtained in the infiltration tests. However, the terrain possesses several attenuation potentials that favor the storage of the studied residues. This is because the field evaluation indicated the chorume presence up to a maximum of $1 \mathrm{~m}$ depth, which had been related to waste disposal held over the last 20 years. Such information/data allow estimate an approximate migration rate equivalent to $0.00000016 \mathrm{~cm} / \mathrm{s}$ that is greatly lower than the values found in the infiltration tests, as well of the maximum guideline value reported in the CETESB Technical Rule No. 024/96/EETR. The differences may be explained by several factors, for instance, the fluid viscosity (water and chorume), presence of organic matter and clay minerals with average cationic exchange capacity, which can be acting as attenuation barriers. Thus, these aspects suggest that the site is, in principle, appropriate for the desired installations, despite further studies would be welcome for assuring the validity of the results reported here.

\section{References}

[1] Uma potência chamada São Paulo; Portal do Governo do Estado de São Paulo, Online. http://www.saopaulo.sp.gov.br/saopaulo

[2] Rocha, G., Mapa de Águas Subterrâneas do Estado de São Paulo-escala 1:1.000.000; DAEE (Departamento de Águas e Energia Elétrica), IG (Instituto Geológico), IPT (Instituto de Pesquisas Tecnológicas do Estado de São Paulo), CPRM (Serviço Geológico do Brasil), São Paulo, 2005.

[3] Almeida, F.F.M. \& Melo, M.S., A bacia do Paraná e o vulcanismo Mesozóico. Mapa geológico do estado de São Paulo, ed. IPT (Instituto de Pesquisas Tecnológicas do Estado de São Paulo), Promocet: São Paulo, v. 1, pp. 46-81, 1981.

[4] Inácio, A. \& Santos, M.J.Z., Características climáticas de Rio Claro. Bol. Geografia Teorética, 18, pp. 87-104, 1988.

[5] Bonotto, D.M. \& Mancini, L.H., Estudo hidroquímico e isotópico dos aqüíferos de Rio Claro (SP). Geochim. Brasil., 6, pp. 153-167, 1992. 
[6] Penteado, M.M., Geomorfologia do setor centro-ocidental da Depressão Periférica paulista. Série Teses e Monografias, 22, 1976.

[7] Camargo, M.N., Klamt, E. \& Kauffman, J.H., Classificação de solos usada em levantamentos pedológicos no Brasil. Sociedade Brasileira de Ciência do Solo: Campinas, 24 pp., 1987.

[8] Tavares, A.C., Prochnow, C.A.C., Risso, L.C., Lazarine, J.A., Tombolato, J.O. \& Penatti, A.P.R., Atlas Climático de Rio Claro. IGCE-UNESP: Rio Claro, 65 pp., 1995.

[9] IAC (Instituto Agronômico de Campinas), Balanço Hídrico do Município de Rio Claro. IAC: Campinas, 1995.

[10] ABGE (Associação Brasileira de Geologia de Engenharia), Ensaios de Permeabilidade em Solos. ABGE: São Paulo, Bol. 4, 30 pp., 1981.

[11] Castany, G., Traité pratique des eaux souterraines. Dunod: Paris, 1967. 